\title{
Regional Social Sustainability Index in Indonesia 2017
}

\author{
Fahrulraz M. Faruk ${ }^{1}$ \\ Statistics of Halmahera Tengah - Indonesia
}

\begin{abstract}
The realization of Social Sustainability is one of the important indicators of achieving sustainable development goals (SDGs) in 2030. The social aspect becomes an important indicator in measuring the achievement of sustainable development with a human approach as the subject. This study produces a composite index that will be used to compare social development between provinces in Indonesia. Besides, this study also analyzes the relationship between the Social Sustainability Index (SSI) formed, with the human development index (HDI) and GRDP per capita. This analysis is used to see the extent to which achievements in human and economic development affect social sustainability.
\end{abstract}

Keywords : Social, Sustainability, Development

${ }^{1}$ Fahrulraz M. Faruk, Statistician in Statistics Indonesia, Poros Weda Payahe Street, Central Halmahera, North Maluku, E-mail : fahrul.mf@bps.go.id 


\title{
Regional Social Sustainability Index in Indonesia 2017
}

\author{
Fahrulraz M. Faruk
}

\section{Introduction}

Sustainable development is based on three concepts: socio-economic development that is in line with ecological constraints, redistribution of resources, and long-term use of resources in ensuring the quality of life needed for future generations. The basis of sustainable development comes from the triple bottom line concept, which implies a balance between the three pillars of sustainability: environmental, social, and economic (Klarin, 2018; McKenzie, 2004). Sustainable development is expected to provide solutions to meeting basic human needs, integrating development and environmental protection, achieving equality, social development, cultural diversity, and maintaining ecological integrity (Klarin, 2018).

Developing countries show that development will be effective if it is carried out in a balanced manner for each dimension. The concept of sustainability emphasizes the importance of economic development accompanied by environmental management and social progress. The main focus is not only targeting economic aspects but also social aspects related to equitable welfare. (Ginandjar Kartasasmita, 1996; Kurniawan \& Managi, 2018). Because based on experience, a development that is only oriented to growth is not effective in increasing human dignity (Wirutomo, 2013). Therefore social approaches must be widely used for development to be effective.

Social development is an important part of sustainable development. Initially, the discussion on sustainable development only related to economic and environmental issues. But in recent years, the social dimension has increasingly been recognized as one of the indicators that have become a basic component of sustainable development (Colantonio, 2008). Some people even believe that the social dimension has become a major aspect of sustainable development (Rasouli \& Kumarasuriyar, 2016). Most of the rhetoric of sustainable development in recent years has emphasized the importance of social justice (Bramley et al., 2006). Social development basically, refers to how human units (individuals, households/families) not only get a decent and adequate life but can also maintain it (Chambers \& Conway, 1992).

\subsection{Social Sustainability in Indonesia}

There are still many problems with social development in Indonesia. Regional disparities, poverty, access to infrastructure, and inequality, are some examples (Arianto \& Wirasenjaya, 2019). Poverty is still a major issue and is often used to measure the level of community welfare.

Although statistically since 2000, the number of poor people in Indonesia has continued to decline, in absolute numbers this number is still very large (until 2017, around 26 million people) (Ishartono dan Raharjo, 2016). The problem is because the impact of the economic climate that is still difficult for the poor. Issues such as rising food prices, removing fuel subsidies and decreasing real farmer's wages, contribute to slowing the decline in the number of poor people (Yusuf \& Sumner, 2015). Boediono (2017), said that the slowdown was caused by the unequal redistribution of assets. Economic growth, which is only five percent more favors the non-poor group than the poor group.

These problems in the medium term try to be reduced by the government through policies in the infrastructure sector and the expansion of social spending. Yusuf and Sumner (2015), said that if the policies of President Jokowi's administration, especially 
those relating to the expansion of social spending (especially in education) can be carried out effectively and progressively, the impact given to poverty reduction will be significant.

Social development in Indonesia is also reflected in the figures for the human development index (HDI) which measures the level of human development based on three indicators, namely life expectancy, mean years school, and per capita income. HDI can photograph how much the quality of life of Indonesian people. HDI can also be used to compare human development achievements between regions in Indonesia.

Statistics Indonesia (named: BPS) notes that since 2010, the human development index (HDI) in Indonesia has continued to increase. Figure 1 shows that the level of human development grows linearly.

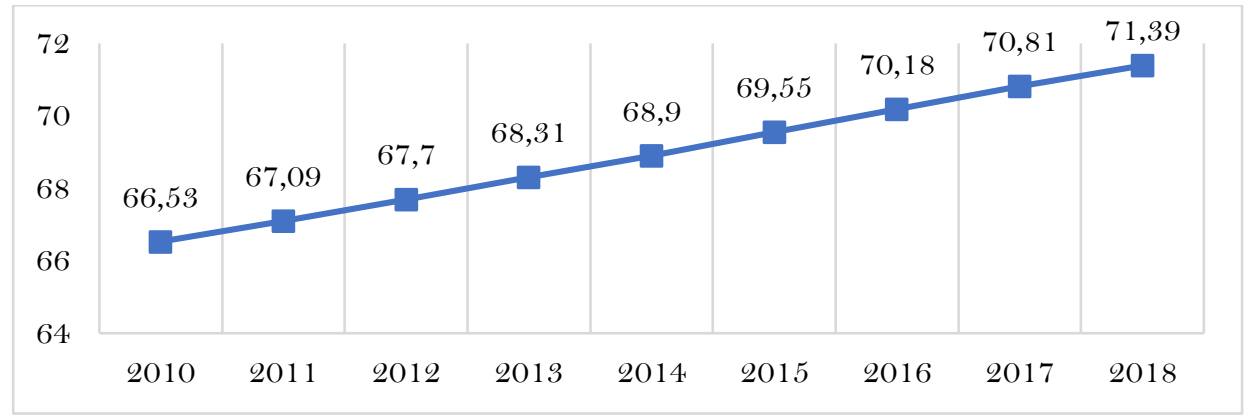

Figure 1. Indonesia's human development index (HDI) 2010-2018 Source: BPS

Although increasing, according to the UNDP (2018), the level of quality of life of the Indonesian people reflected in the Human Development Index (HDI) / HDI, is only 116th out of 189 countries. This ranking is still below other Southeast Asian countries such as the Philippines, Thailand, Malaysia, Brunei Darussalam, and Singapore.

Quality of life is difficult to measure. But some indicators can be used to monitor social development achievements, one of which is the gross domestic product (GDP) per capita. GDP per capita is the value of all goods and services produced in a region over a period divided by the population (CSS, 2018). GDP per capita can be used to see the level of social development through an economic approach.

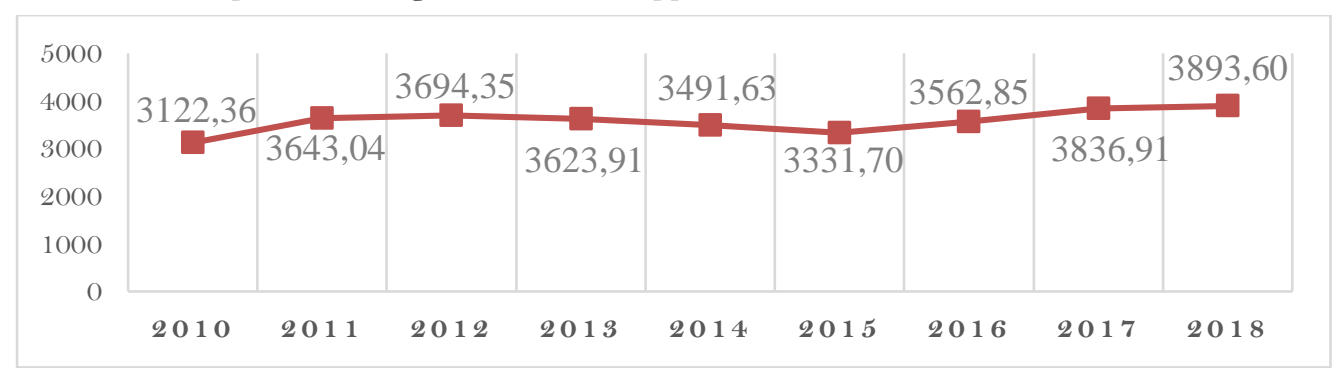

Figure 2. Indonesia's GDP per capita 2010-2018 (000)

\section{Source: BPS}

The World Bank in 2018 placed Indonesia as a lower-middle-income country. Indonesia's ranking is still below that of other ASEAN countries such as Singapore, Malaysia, Brunei Darussalam, and Thailand. Figure 2 shows that Indonesia's GDP per capita since 2010 has fluctuated. GDP per capita continued to decline from 2011 to 2015 but showed an upward trend since 2015 . 
HDI or GDP per capita does not fully reflect the level of social development. HDI is not a comprehensive measure of human development because it only focuses on the basic dimensions. HDI must be combined with other indicators to get a comprehensive illustration of human development (Jahan, 2018). Besides, GDP per capita also actually only measures the level of the economy, not welfare. Development which is only based on GDP will ignore other problems such as environmental degradation and inequality (Kapoor \& Debroy, 2019).

Therefore this research tries to measure the level of social development by combining several additional indicators that aim to capture some facts that cannot be explained by the economic aspects. This study will portray the sustainable social development of Indonesia's provinces from two dimensions: well-being and quality of life. This measurement is important because since decentralization was implemented, the region has the biggest role in defining sustainable development goals (INFID, 2016). Regions, in this case, have the most ideal position to be able to identify more closely the people who live in poverty and various other developmental problems such as food security, health, and education (UCLG, 2016).

This study also uses economic and environmental indicators to measure the achievements of social development in Indonesia. The result will be a composite index that will be used to see the ranking of regions based on the level of social development. Also, this study will look at the effect of HDI and GDP per capita on social development.

Based on the concepts that have been explained, research questions that explain the purpose of this study are:

1. How does social development compare between provinces in Indonesia?

2. How accurate are HDI and GDP per capita in describing the level of social sustainability in Indonesia?

\subsection{Conseptual Framework}

It is not easy to define the word "social" because it has a very broad understanding. The definition of "social" includes various aspects, such as law, politics, and even economics. In the concept of development, "social" can be interpreted as an aspect of fulfilling rights and needs following human dignity. "Social" aspects target sectors that are directly related to people and society, such as education and health. Therefore, social development can be defined as an effort to improve welfare through an approach that focuses on human values by optimally increasing the potential of people/communities (Ginandjar Kartasasmita, 1996).

Social sustainability can also be defined as an effort to meet basic human needs based on the principles of justice, equality, convenience, and social security for present and future generations (Rasouli \& Kumarasuriyar, 2016). Attention to social sustainability is still limited, especially those related to theory. The environmental and economic dimensions still dominate most research on sustainable development (Spangenberg \& Omann, 2006).

Some researchers in measuring the achievements of social development, using many indicators both directly related to the fulfillment of human needs, as well as those related to the quality of life. Rasouli \& Kumarasuriyar (2016) and Spangenberg (2004), explained that two levels can be used to measure social development achievements: micro and macro. The macro-level refers to the dimensions related to welfare, income distribution, and those related to meeting basic human needs such as housing, food, and clothing. While the micro-level is about quality of life, education, communication, and social justice. Some social development indicators used in several studies can be seen in the following table. 
Table 1 Social sustainability indicators used in previous studies

\begin{tabular}{|l|l|}
\hline \multicolumn{1}{|c|}{ Researcher } & \multicolumn{1}{c|}{ Indicators } \\
\hline DESA-UN (2007) & Poverty, governance, health, education, demographics. \\
\hline McKenzie (2004) & Equality (access to key services, generation), democracy. \\
\hline Neamţu (2012) & $\begin{array}{l}\text { Traditional: Basic needs, education, work, gender, social justice. } \\
\text { Recent: demographic change, social capital, health and security, } \\
\text { well-being, happiness and quality of life. }\end{array}$ \\
\hline OECD (2009) & Independence, health, equality, social cohesion. \\
\hline
\end{tabular}

Based on the above foundation, the conceptual work in this study will be divided into two dimensions: well-being and quality of life. The well-being dimension consists of welfare indicators such as poverty, health and sanitation, meeting basic needs, and housing. While the quality of life is related to skills, education, information and communication, the environment, happiness, and democracy. Indicators for measuring the social sustainability composite index (SSI) adjust to the indicators used by the United Nations in measuring SDG's achievements.

Social Sustainability
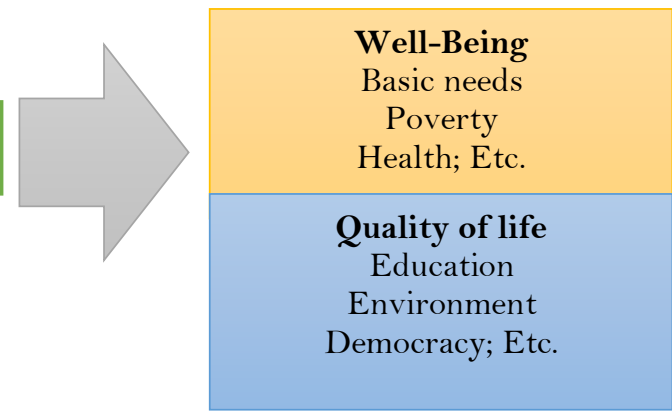

Figure 3. Research framework

II. Data 
The data used in this study are from 34 provinces in Indonesia, which come from several BPS publications and the Ministry of environment and forestry (KLHK). Some indicators used include the percentage of poor population, life expectancy, mean years of schooling, civil index, and environmental quality index (EQI). The indicators used in this study can be seen in the following table 2 .

Table 2. The indicators making up the social sustainability index (SSI) by dimension.

\begin{tabular}{|c|c|}
\hline Dimension & Indicator \\
\hline \multirow{11}{*}{ Well-Being } & Percentage of population living below the poverty line (BPS) \\
\hline & Percentage of urban slum households (BPS) \\
\hline & Prevalence of malnutrition in children under five (BPS) \\
\hline & $\begin{array}{l}\text { Percentage of households that have access to decent drinking water } \\
\text { sources (BPS) }\end{array}$ \\
\hline & $\begin{array}{l}\text { Proportion of population that has hand washing facilities with soap } \\
\text { and water (BPS) }\end{array}$ \\
\hline & $\begin{array}{l}\text { Percentage of households that have access to proper sanitation } \\
\text { services (BPS) }\end{array}$ \\
\hline & $\begin{array}{l}\text { Percentage of women ever married aged } 15-49 \text { who had their last } \\
\text { birth at a health facility (BPS) }\end{array}$ \\
\hline & $\begin{array}{l}\text { Prevalence of stunting (very short) in children under five years old } \\
\text { (BPS) }\end{array}$ \\
\hline & $\begin{array}{l}\text { Proportion of households that have access to decent and affordable } \\
\text { housing (BPS) }\end{array}$ \\
\hline & $\begin{array}{l}\text { Proportion of population with minimum calorie intake below } 1400 \\
\text { kcal / capita / day (BPS) }\end{array}$ \\
\hline & $\begin{array}{l}\text { Percentage of households that use electricity source lighting } \\
\text { (population } 40 \% \text { low income) (BPS) }\end{array}$ \\
\hline \multirow{14}{*}{ Quality of Life } & Life expectancy rate (BPS) \\
\hline & Average School Life Age $\geq 15$ Years (BPS) \\
\hline & Percentage of household owns cellular phone (BPS) \\
\hline & Percentage of formal employment (BPS) \\
\hline & Underemployment rate (BPS) \\
\hline & Per capita expenditure adjusted (BPS) \\
\hline & Proportion of individuals using the Internet (BPS) \\
\hline & Civil liberties index (BPS) \\
\hline & Political rights index (BPS) \\
\hline & $\begin{array}{l}\text { The proportion of children under } 5 \text { years of age whose birth is } \\
\text { recorded by civil registration agencies (BPS) }\end{array}$ \\
\hline & Environmental quality index (EQI) (KLHK) \\
\hline & Percentage literacy rate of population aged $\geq 15$ years (BPS) \\
\hline & $\begin{array}{l}\text { Proportion of adolescents and adults with information and } \\
\text { communication technology skills (BPS) }\end{array}$ \\
\hline & Happiness index (BPS) \\
\hline
\end{tabular}

\section{Analytical Method}

This study uses two analytical methods: descriptive and inferencing. Inferencing analysis is used to compile a composite index and see the relationship between the resulting composite index and related indicators. The preparation of SSI in this study uses the factor analyst method. Besides, we also use the analysis of the relationship between variables (Pearson correlation coefficient and linear regression) to check the relationship between the composite index with related indicators. 
Factor Analysis is an exploratory technique applied to a set of observed variables to find the factors of the observed variables. Factor analysis aims to describe a set of variables $\mathrm{Q}, \mathrm{x} 1, \mathrm{x} 2, \ldots, \mathrm{xQ}$ from a small number of factors $\mathrm{m}$, and to see the relationship between these variables. Factor analysis grouping variables in large numbers, into several factors that have almost the same characteristics. Factor scores resulting from factor analysis can be used for further analysis (OECD, 2008; Wiratmanto, 2014).

Factor analysis is used to reduce the number of variables. The aim is to simplify the process of making a composite index. The results of the factor analysis are scores that will be used to compile the composite index. The stages of making a composite index with factor analysis adjust to the methods used by the United Nations (UN) and OECD. Composite index calculation can be divided into 3 stages:

1. Data normalization

2. Factor analysis

3. Composite index calculation

Data normalization is intended to standardize data into the same unit of measurement. After normalizing the data, the next step is to conduct a factor analysis to obtain a factor score and a weight that will be used for the construction of the composite index. Factor analysis is performed on each dimension (welfare \& quality of life) so that each of the two dimensions will have their own index numbers. SSI obtained from the average of the sum of the well-being and quality of life index. The resulting composite index will then be used for further analysis to see the relationship between the SSI produced with the HDI as well as the per capita GRDP using Pearson correlation analysis and regression analysis.

Besides, descriptive analysis is used to classify provinces based on SSI. Grouping uses the assumption that SSI values are normally distributed. the provinces are grouped into three categories (high, medium, low) which are described in the form of a thematic map. The methods for categorizing the index of sustainable social development for each province are as follows:

1. High : $\mathrm{SSI}>\mu+\mathrm{Z}_{\alpha / 2} \sigma / \sqrt{\mathrm{n}}_{\mathrm{n}}$

2. Medium : $\mu-Z_{\alpha / 2} \sigma / \sqrt{n}_{n}>$ SSI $>\mu+Z_{\alpha / 2} \sigma / \sqrt{n}_{n}$

3. Low :SSI $<\mu-Z_{\alpha / 2} \sigma / \vee_{n}$

Also, we use the typology Klassen/quadrant analysis to see the relationship between SSI, HDI, and per capita Gross Regional Domestic Product (GRDP).

\section{Result}

\subsection{Analysis Results}

Factor analysis yields SSI for 34 provinces in Indonesia. This composite index is used to rank provinces by the level of social sustainability. Figure 4. shows the social sustainability index according to well-being indicators. 


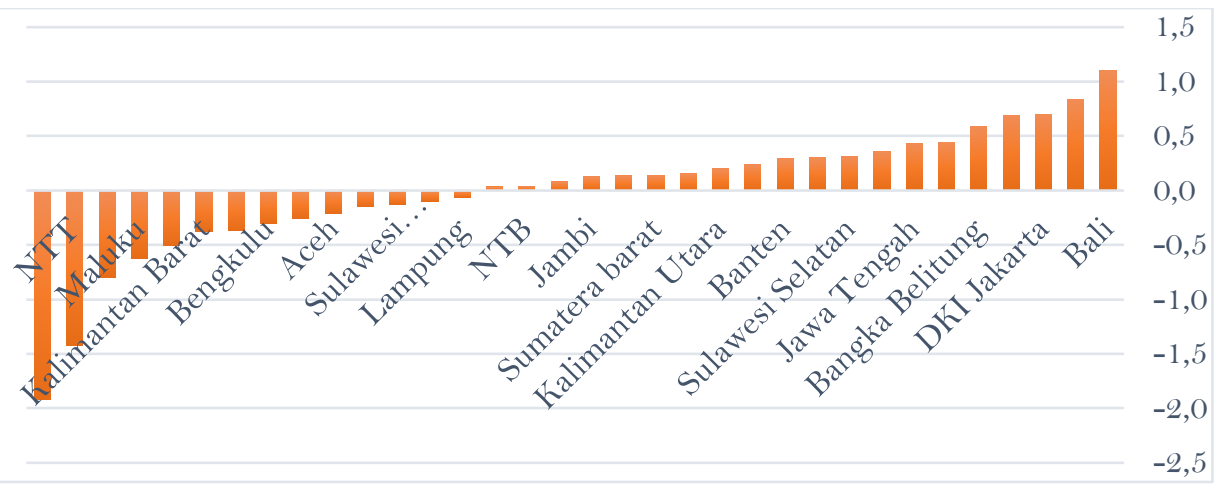

Figure 4. The well-being index of provinces in Indonesia in 2017

Based on Figure 4, we can see that Bali, DI Yogyakarta, and DKI Jakarta are the 3 provinces with the highest well-being index. While the lowest are Papua, Nusa Tenggara Timur (NTT) and Papua Barat. There are 20 provinces that have a well-being index above the average, while 14 provinces are below.

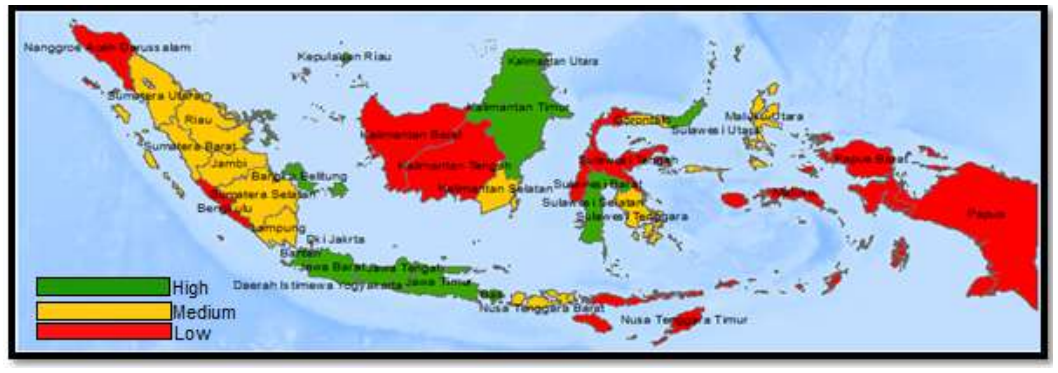

Figure 5. Thematic map of provinces in Indonesia based on 2017 well-being index classification

Based on Figure 5. There are 13 provinces with a high well-being index, 11 in medium, and 10 in low. Java has the best well-being indicator compared to other islands because all provinces in Java are in the high category. As for the provinces with low categories, there are two in Sumatra, two in Kalimantan, two in Sulawesi, one for the Bali and Nusa Tenggara, and three for Maluku and Papua.

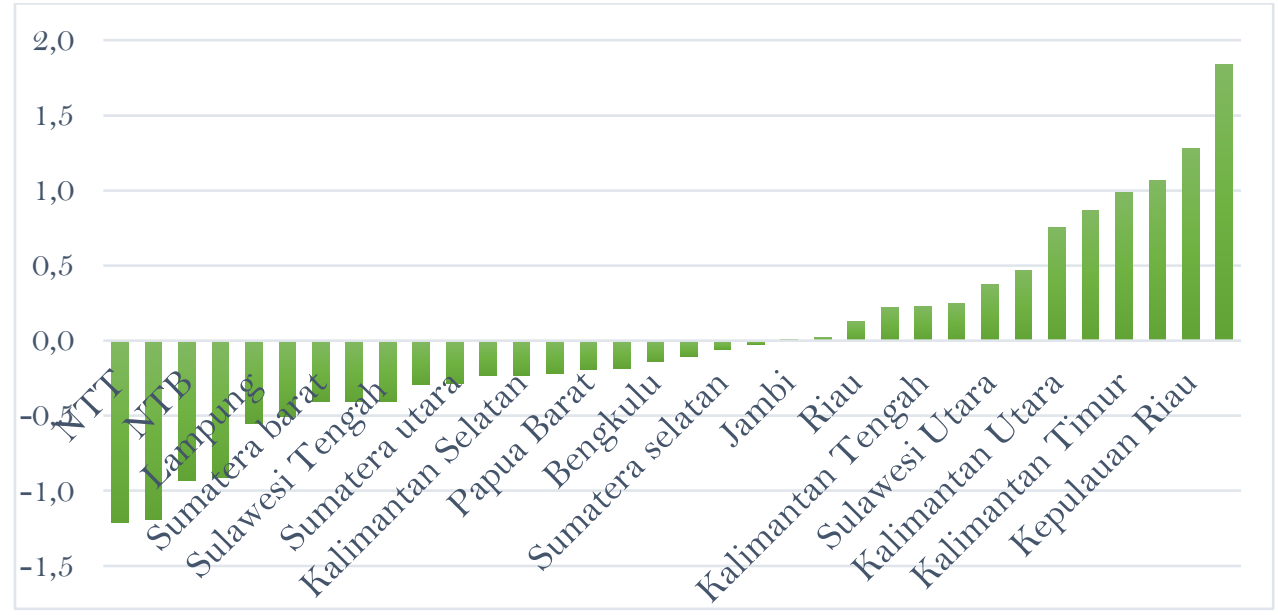

Figure 6. Quality of life index of provinces in Indonesia in 2017 
Based on figure 6. We can see that for indicators of quality of life, DKI Jakarta, Kep. Riau, and DI Yogyakarta are the three provinces with the highest quality of life. Whereas NTT, Papua and Nusa Tenggara Barat (NTB) are the three provinces with the lowest quality of life. There are 14 provinces that have a quality of life above the average, while the rest are still below.

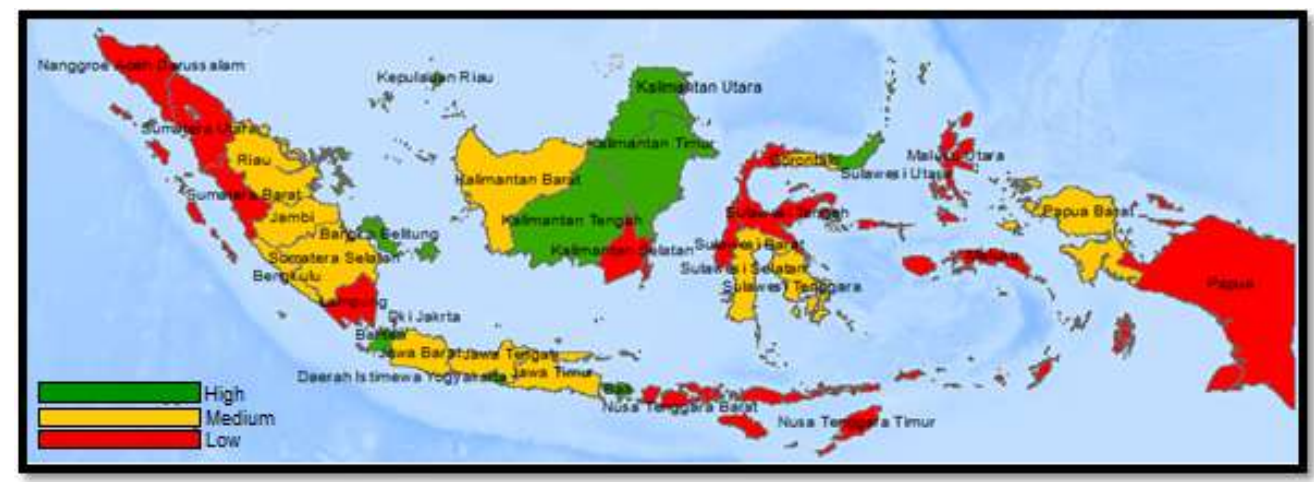

Figure 7. Thematic map of provinces in Indonesia based on 2017 quality of life index classification

In contrast to the well-being index, most provinces in Indonesia have a low quality of life index. Based on figure 7. 13 provinces still have a low quality of life index. Besides, another interesting thing that can be seen is that despite having a better level of development compared to other islands, some provinces on the island of Java only have a medium quality of life index. There are three provinces in Java that are known to have a medium quality index: Jawa Barat, Jawa Tengah, and Jawa Timur.

Based on figures $4 \& 6$. we can see that the indicators of well-being and quality of life on average are not too different for each province. DKI Jakarta, DI Yogyakarta, Kep. Riau, and Kalimantan timur tend to have high scores for both indicators. Whereas Papua, NTT, Sulawesi Barat and Maluku tend to have low scores. Based on the composite index values generated from the two dimensions above, we can calculate the SSI values obtained from the average of the two dimensions.

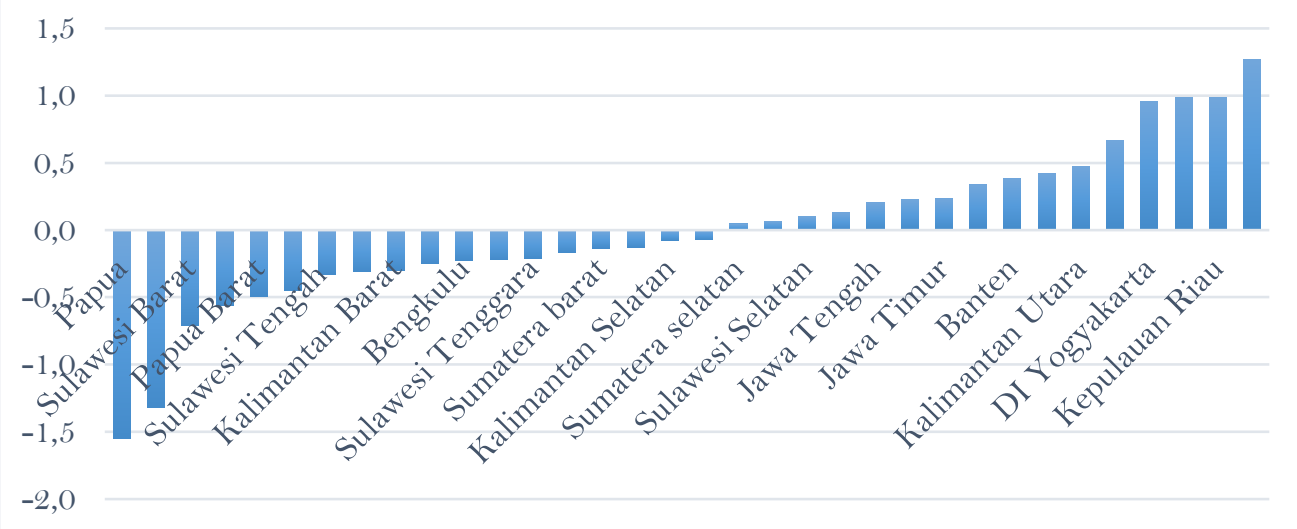

Figure 8. Social sustainability index (SSI) of the provinces in Indonesia

Figure 8 shows the SSI calculated based on the average of the well-being and quality of life index. DKI Jakarta, Kep. Riau, and Bali are the three provinces with the highest SSI. While Papua, NTT, and Sulawesi Barat are the lowest. 


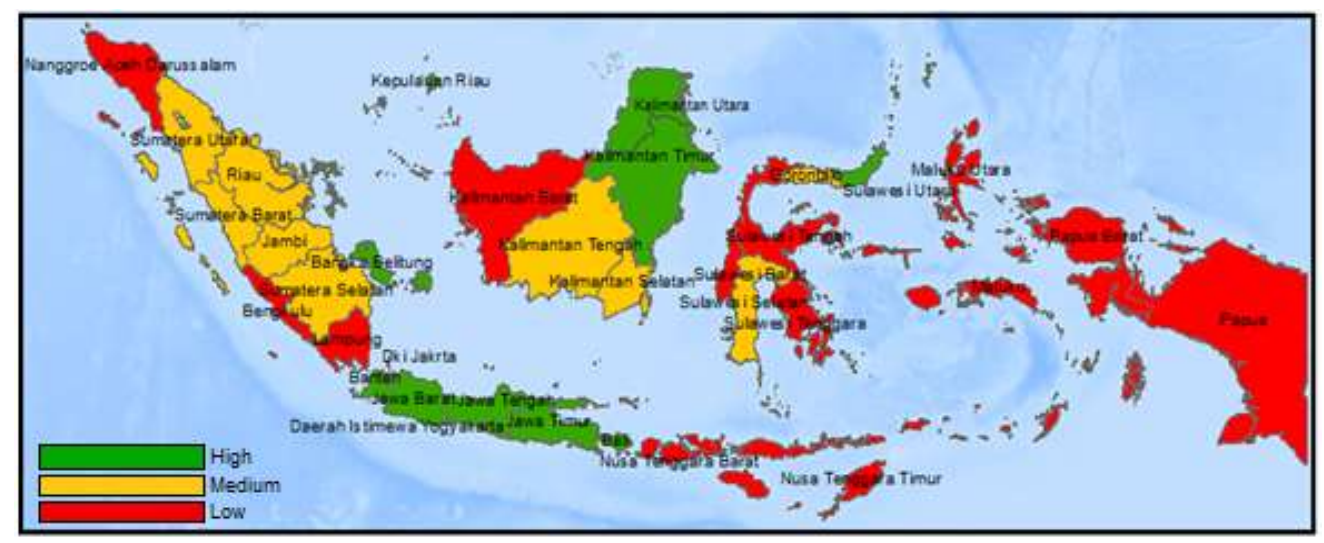

Figure 9. Thematic map of provinces in Indonesia based on the 2017 social sustainability index (SSI) classification

Figure 9 shows that the level of social sustainability varies between regions. 12 provinces have a high SSI, 9 are in the medium, and 13 are in low. Most with high indexes are concentrated in Java. While for the low category, most of them are spread in eastern Indonesia.

\subsection{The relationship between social sustainability index (SSI) with the Human Development Index (HDI) and GRDP per capita}

Provinces with a high SSI on average have a high HDI as well. This can be detected from the results of the quadrant analysis. Based on quadrant charts, it is known that between SSI and HDI are related to each other.

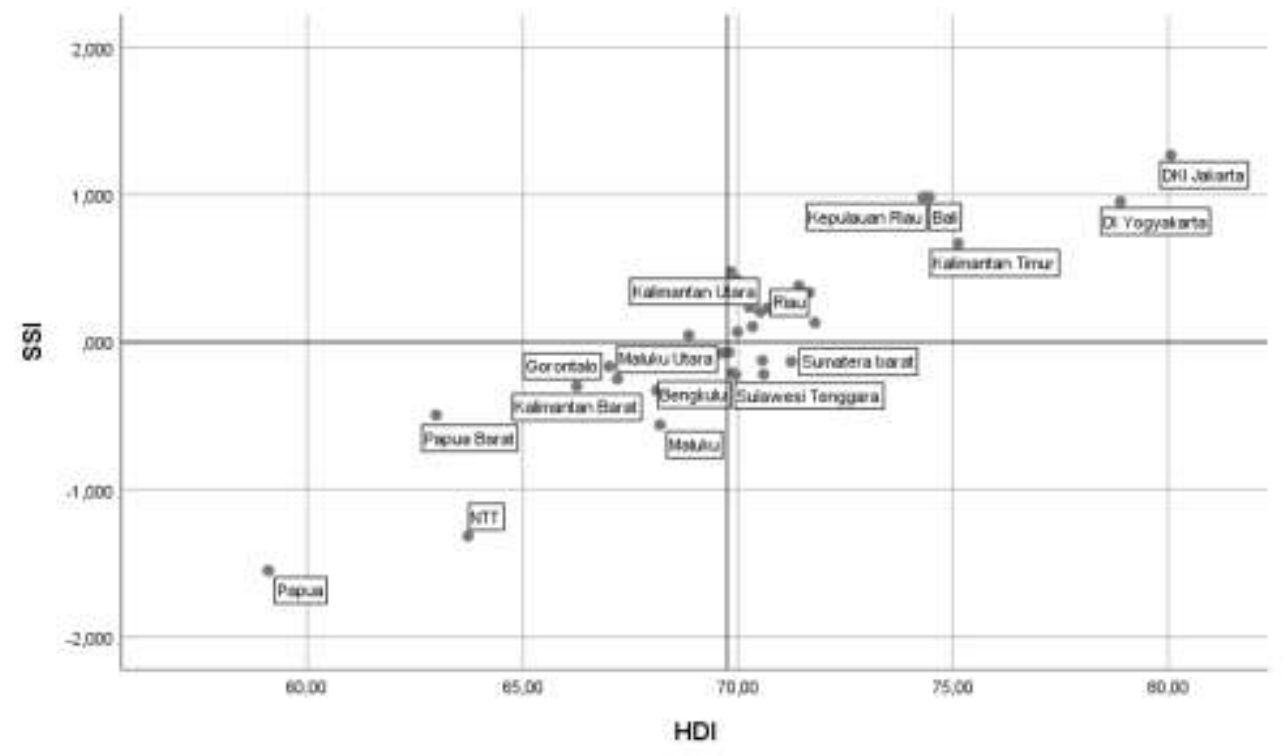

Figure 10. HDI and SSI plot diagram

Figure 9 shows that most provinces are concentrated in quadrants I and III. This means that social sustainability and human development have a linear relationship. A region with a high HDI tends to have a high SSI as well, as well as a low one. DKI Jakarta, DI Yogyakarta, Bali, and Kep. Riau which incidentally have high HDI, also have high SSI. 
While the provinces of Papua, NTT, Papua Barat and Sulawesi Barat which have low SSI, also tend to have low HDI. This indicates that SSI and HDI are related to each other.

Quadrant analysis is also used to see the relationship between SSI and GRDP per capita. Figure 11 shows that provinces with an SSI above average tend to have GRDP per capita above average, as well as low. however, this result is indeed a bit different when compared with SSI and HDI. DI Yogyakarta, which has a high SSI, turns out to have a below-average GRDP per capita. While Papua and Papua Barat, which have a low SSI, actually have a GRDP value per capita that is above average.

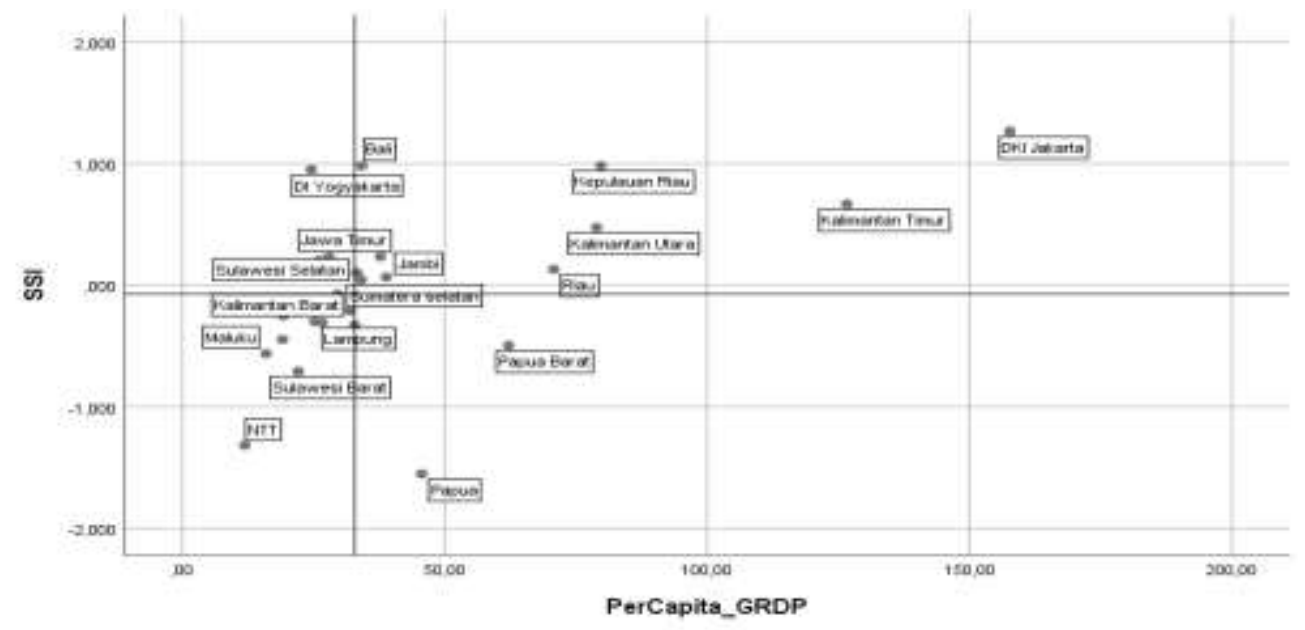

Figure 11. GRDP per capita and SSI plot diagram

To further analyze the relationship between SSI, HDI and GRDP per capita, this study uses a correlation test with Pearson correlation coefficient. Correlation Test aims to see how strong the relationship between the three variables.

Table 3. Pearson correlation analysis of SSI, HDI, and GRDP per capita

\begin{tabular}{|l|l|}
\hline Variable & Pearson Correlation \\
\hline SSI-HDI & 0,914 \\
\hline SSI-GRDP per capita & 0,528 \\
\hline
\end{tabular}

Source: processing results

The Pearson correlation coefficient produced for each indicator is 0.914 and 0.524 , which indicates that each has a very and quite strong relationship. Besides, the three variables also showed a positive relationship. This means that any increase in one variable will affect the increase in other variables.

In addition to the correlation test, multiple linear regression is also used to see how significant the effect of HDI and GRDP per capita on SSI. The results of the RLB test can be seen in the following table 4 . 
Table 4. The results of multiple linear regression analysis between SSI with HDI and GRDP per capita

\begin{tabular}{ccccc}
\hline \hline & & & & \\
Variable & Coefficient & Std. Error & t-Statistic & Prob. \\
\hline \hline C & & & & \\
HDI & -8.889651 & 0.801146 & -11.09617 & 0.0000 \\
GRDP per capita & 0.126268 & 0.011892 & 10.61760 & 0.0000 \\
\hline \hline
\end{tabular}

Source: processing results

Based on table 4, the HDI variable significantly influences the SSI with a significance value of 0,000 or smaller than the 0.05 significance level. With the assumption test requirements being met, and the coefficient value of $\mathrm{B} 0.1263$, then the interpretation is for each additional HDI of 1 unit, which can increase the SSI of 0.1263 . Therefore the focus on increasing HDI will indirectly have a significant effect on social development.

Also, the results of the regression test showed that GRDP per capita did not have a significant effect on SSI because it had a significant value that was greater than the 0.05 significance level. Therefore, it can be concluded that an increase in per capita GRDP does not necessarily have an impact on increasing sustainable social development.

\section{Discussion}

Apart from being an island with a high level of economic development, Java also apparently still dominates in social development. When referring to the well-being dimension, all provinces in Java have a high index value. But based on the quality of life dimension, only three of the six provinces have a high index value Environmental indicators are thought to be the cause not all provinces in Java do not have a high quality of life index. According to the KLHK report, all provinces in Java do have a low EQI. Therefore the quality of the environment is one of the important issues that must be prioritized in social sustainability in Java.

Meanwhile, most provinces in eastern Indonesia also still have a low SSI. This indicates that the imbalance of social development between regions still occurs. Incentives and alignments should be prioritized, especially for emerging regions such as Sulawesi, Maluku, Nusa Tenggara, and Papua (Firdaus, 2013). Ease of access to education, health, and employment has a direct effect on reducing income inequality (Wicaksono et al., 2017). Therefore, the focus of development on these three aspects is expected to reduce inequality in social development.

The dimensions of education, health, and income reflected in HDI affect increasing social development. Although these dimensions are also used to arrange factors in the SSI, statistically, the effect on social development is quite high. The increase in the three dimensions of HDI affects the dimensions of well-being and quality of life.

Besides, this study also found that an increase in per capita GRDP did not have a significant effect on increasing SSI. This means that economic growth has not had a significant impact on social development. We believe that this may be due to the high inequality in income. This problem, as explained by Boediono (2017) \& Wicaksono et al. (2017) in their study that high economic growth does not always have a direct impact on 
poverty reduction. High growth if not followed by a proportional distribution of assets will exacerbate inequality.

\section{Conclusion}

Social sustainability is one of the important indicators to monitor SDG's achievements in Indonesia. This research found that social development is still concentrated in a few regions. Regions with high well-being index such as Bali, DI Yogyakarta, DKI Jakarta, and Kep. Riau tends to have a good quality of life. Likewise with regions with a low well-being index. The SSI Value also shows that most provinces in Indonesia still have low social development achievements, especially in the eastern region. In the process of policymaking later, the focus is not only limited to the region (east and west) but also has to target areas that still have low achievements.

Besides, this study also found that HDI variables were more accurate in explaining social sustainability in Indonesia compared to GRDP per capita. The results found that human development indicators provide a more direct impact on social sustainability than economics. Therefore, factors directly related to human development such as education, health, and welfare are the main keys to social sustainability in Indonesia.

The process of social sustainability must focus on indicators related to the dimensions of well-being and quality of life with the aim of full human development. The ultimate goal is to achieve SDG's in 2030 and to realize the vision of onward Indonesia in 2045.

\section{Reference}

Arianto, Z., \& Wirasenjaya, A. M. (2019). President Joko Widodo's Effort in Implementing Sustainable Development Goals in Indonesia. Yogyakarta.

Boediono. (2017). Revisiting the Problem of Development Distribution. Bulletin of Indonesian Economic Studies, $\quad$ 53(2), $211-217$. https://doi.org/10.1080/00074918.2017.1373317

Bramley, G., Dempsey, N., Power, S., \& Brown, C. (2006). What Is 'Social Sustainability', And How Do Our Existing Urban Forms Perform In Nurturing It. Sustainable Communities and Green Futures. London: UCL.

Chambers, R., \& Conway, G. R. (1992). Sustainable rural livelihoods: practical concepts for the 21st century. In IDS Discussion Paper (Vol. 296).

Colantonio, A. (2008). Measuring Social Sustainability: Best Practice from Urban Renewal in the EU. Oxford.

CSS. (2018). Social Development Indicators. Michigan: University of Michigan.

DESA-UN. (2007). Indicators of Sustainable Development: Guidelines and Methodologies. https://doi.org/10.1016/j.cirpj.2010.03.002

Fauzi, A., dan Oxtavianus, A. (2014). Pengukuran Pembangunan Berkelanjutan di Indonesia. MIMBAR, Jurnal Sosial Dan Pembangunan, 30(1), 42. https://doi.org/10.29313/mimbar.v30i1.445

Firdaus, M. (2013). Ketimpangan Pembangunan antar Wilayah di Indonesia. 1-54. Bogor: Institut Pertanian Bogor.

Ginandjar Kartasasmita. (1996). Kebijakan dan Pembangunan Sosial. Malang: Universitas Brawijaya.

INFID. (2016). Sustainable Development Goals-SDGs Panduan Untuk Pemerintah Daerah (Kota dan Kabupaten) dan Pemangku Kepentingan Daerah (Edisi Revisi). Jakarta: INFID.

Ishartono, dan Raharjo, S. T. (2016). Sustainable Development Goals (SDGs) dan Pengentasan Kemiskinan. Social Work Jurnal, 6(2), 154-272.

Jahan, S. (2018). The Human Development Index - what it is and what it is not. Retrieved October 20, 2019, from UNDP.org website: http://hdr.undp.org/en/hdi-what-it-is

Kapoor, A., \& Debroy, B. (2019). GDP Is Not a Measure of Human Well-Being. Retrieved 
October 10, 2019, from Harvard Business Review website: https://hbr.org/2019/10/gdp-is-not-a-measure-of-human-well-being

Klarin, T. (2018). The Concept of Sustainable Development: From its Beginning to the Contemporary Issues. Zagreb International Review of Economics and Business, 21(1), 6794. https://doi.org/10.2478/zireb-2018-0005

Kurniawan, R., \& Managi, S. (2018). Economic Growth and Sustainable Development in Indonesia: An Assessment *. Bulletin of Indonesian Economic Studies, 54(3), 339-361. https://doi.org/10.1080/00074918.2018.1450962

McKenzie, S. (2004). Social Sustainability: Towards Some Definitions. In University of South Australia. Magill.

Neamţu, B. (2012). Measuring the social sustainability of urban communities: The role of local authorities. Transylvanian Review of Administrative Sciences, (37), 112-127.

OECD. (2008). Handbook on Constructing Composite Indicators. Paris: OECD.

OECD. (2009). Headline Social Indicators. https://doi.org/10.1787/soc_glance-2008-2-en

Rasouli, A. H., \& Kumarasuriyar, D. A. (2016). The Social Dimention of Sustainability: Towards Some Definitions and Analysis. Journal of Social Science for Policy Implications, 4(2), 23-34. https://doi.org/10.15640/jsspi.v4n2a3

Spangenberg, J. H. (2004). Reconciling sustainability and growth: Criteria, indicators, policies. Sustainable Development, 12(2), 74-86. https://doi.org/10.1002/sd.229

Spangenberg, J. H., \& Omann, I. (2006). Assessing social sustainability: Social sustainability and its multicriteria assessment in a sustainability scenario for Germany. International Journal of Innovation and Sustainable Development, 1(4), 318348. https://doi.org/10.1504/IJISD.2006.013734

UCLG. (2016). Tujuan Pembangunan Berkelanjutan yang Perlu Diketahi oleh Pemerintah Daerah. Jakarta: UCLG.

UNDP. (2018). Human Development Indices and Indicators. 2018 Statistical Update. New York: United Nations Development Programme.

Wicaksono, E., Amir, H., \& Nugroho, A. (2017). inequality income in Indonesia: Asian Development Bank Institute. ADBI Working Paper Series, (667).

Wiratmanto. (2014). Analisis Faktor dan Penerapannya Dalam Mengidentifikasi Faktor Faktor Tang Mempengaruhi Kepuasan Konsumen Terhadap Penjualan Media Pembelajaran. Universitas Negeri Yogyakarta.

Wirutomo, P. (2013). Mencari Makna Pembangunan Sosial: Studi Kasus Sektor Informal di Kota Solo. MASYARAKAT: Jurnal Sosiologi, 18(1), 101-120. https://doi.org/10.7454/mjs.v18i1.3735

Yusuf, A. A., \& Sumner, A. (2015). Growth, Poverty and Inequality under Jokowi. Bulletin of Indonesian Economic Studies, 51(3), 323-348. https://doi.org/10.1080/00074918.2015.1110685 